\title{
Public Procurement and Public Service Delivery in Zimbabwe Local Authorities. A Non-systematic Review
}

\author{
Moses Jachi* Melania Makumbe Lucia Mandongwe \\ Manicaland State University of Applied Sciences P. Bag 7001, Mutare, Zimbabwe
}

\begin{abstract}
The study attempts to theoretically explore the influence of public procurement decisions on public service delivery and to propose a structure of the relationship between an efficient public procurement system and the effectiveness of public service delivery. The study hypothesizes that there is a positive relationship between efficient public procurement and effective public service delivery in Zimbabwe local authorities, taking into consideration the mediating effect of corporate governance practices. The study briefly explores the historical background of procurement as an emerging corporate administrative function. Also, a brief review of the relationship between public procurement and public service delivery is outlined. The main objective of this study is to fill the gap in literature on the link between public procurement and public service delivery, and provide an opportunity for future studies to deeply and empirically investigate this relationship.
\end{abstract}

Keywords: Public procurement, Public service delivery, Corporate governance

DOI: $10.7176 / \mathrm{PPAR} / 9-12-05$

Publication date: December $31^{\text {st }} 2019$

\section{Introduction}

The scantiness of literature on public procurement is clear evidence that the profession is still relatively new (Flynn \& Paul, 2014), and there are few documented theories on the subject (Basheka, 2013; Flynn \& Paul, 2014). It is evident that little interest has been devoted to the subject of procurement, most probably because it appears as if the performance of procurement functions require little or no skills as compared to other disciplines within management sciences, the likes of human resource management, marketing, accounting and finance (Chick \& Handfield, 2014). Thus, this therefore can be used to explain why to date, procurement still resides at the periphery of management sciences.

Notwithstanding the fact that the original publications which defines the academic foundations of procurement surfaced in the 1970s, with the first procurement textbooks authored by England (1970), Lee and Dobler (1971) and Bailey and Farmer (1977), an increase in publications on the subject was felt in the early 90s (Chick \& Handfield, 2014). This relative lack of literature on procurement in general, and public procurement specifically, partially explains why not much research has been carried out to date, to demystify the influence of public procurement on public service delivery (Basheka, 2013; Chick \& Handfield, 2014). Although there is a noticeable improvement in academic attention directed towards procurement research, the direction it has taken still does not fully address questions on the emerging debate concerning the relationship between public procurement and public service delivery, as much of the studies focus on organizational level aspects more than regulatory policy issues. It can also be appreciated that more research to date has been in the context of developed nations, particularly the North American and European regions (Flynn \& Paul, 2014). In African context and other developing regions, most procurement scholars are those individuals who had taken part, or are taking part in public procurement reforms and capacity development in their respective countries (Basheka, 2013; Flynn \& Paul, 2014). Evidence form the available literature points to the notion that public procurement is a critical component of public service delivery. However, its explicit elaboration is still lacking, particularly in the context of developing countries, specifically in Zimbabwe.

\section{A brief history of procurement}

The term 'purchasing' function which represent part of the modern procurement, has been in existence since the commencement of organized trading (Callendar \& Mathews, 2000), pointing to the long history of procurement practices (Thai, 2001). Evidence of early forms of procurement is available in various forms and pieces of literature. These include the silk trade between China and Greek colony which emerged during the $18^{\text {th }}$ century (800BC) (Fuwei, 1996); contracts entered in support of the Roman army in Spain around 300 BC (Livy, 1966; Callendar \& Mathews, 2000; Grimm \& Thai, 2000). Also, in Syria, it is reported that evidence of the earliest procurement order was written on a red clay tablet between 2400-2800BC (Grimm \& Thai, 2000; Thai, 2001). This was an order of 50 jars of fragrant smooth oil for 600 small weights of grain (Coe, 1989; Thai, 2001). Manifestation of procurement practices was also evident in Egypt in 300BC, during the construction of the pyramids (Grimm \& Thai, 2000; Thai, 2001; Basheka, 2013).

The United States procurement system, as is the case with its legal system, can be traced back to England. English colonists brought with them the English common law, and with it, the English system of military 
procurement (Keeney, 2007). According to Keeney (2007), most of the military supplies requirements to the government were sourced by commissaries for a commission. By the mid- $18^{\text {th }}$ century, the British field army had the responsibility for obtaining its supplies locally. The commissary general was responsible for the acquisition of food stuffs and related items, the quartermaster general was responsible for transportation, construction and other supplies. It was noted that during that time, procurement was based on a trial and error, as a result, a secret committee of trade was established in 1775, during English trade embargo, taking over responsibility for military supplies (Nuxoll, 2006; Keeney, 2007). During this period, taking a kickback from a contractor was actually an expected means of compensation for the Royal Navy clerks, the then contracting officers, and such an act was neither illegal nor unethical (Miller, 1992; Siri, 2005; Keeney, 2007), mainly because Royal Navy clerkship was an unpaid civil service post in London. The inconsistencies and irregularities associated with this form of early procurement practices motivated the crafting of the first procurement legislation, passed by the US congress in 1792. This act bestowed authority upon the Department of War and Treasury to administer contractual arrangements on behalf of the nation (Callendar \& Mathews, 2000; Keeney, 2007).

The year 1678 saw the announcement of the first tender in Japan, for the construction of a bridge at Reigarijima and Minamikayabacho and repair of a trunk road in Edo (Isohata, 2009). A number of currently popular contracting practices were introduced between 1798 and the early $19^{\text {th }}$ century, addressing challenges faced in supplying troops in the Western frontier. By 1900, separate procurement departments were now visible. In the 1950s and 60s, procurement continued to gain ground, with the refinement of procurement methodologies and techniques and increase in trained professionals. The 1980s and 90s saw further developments in procurement, with the publication of several books and articles on procurement (Chick \& Handfield, 2014), bringing to light procurement as an equally important administrative function. However, there was still lack of harmony and common understanding as some stakeholders portray the procurement function as a "passive, reactive and tactical service", while others portrayed it as an "advanced, integrative and strategic function". Of significant contribution to the organization and recognition of procurement practices is the emergence of public bodies and inter-governmental organizations. Inter-governmental organizations and development partners, the likes of the World Bank, International Monetary Fund, and World Trade Organization contributed significantly towards development of procurement practices in Africa through policy reforms (Agaba \& Shipman, 2007).

Procurement in Africa, mainly in independent states was dominantly guided by unclear laws and regulation, prone to abuse and manipulation (Odhiambo \& Kamau, 2003). Procurement reforms are then meant to establish a strong, well-functioning procurement systems governed by clear legal and institutional frameworks. It can therefore be noted that one of the main motives behind procurement reforms is undeniably the need to ensure the public procurement system is capable of adding value towards public service delivery (Basheka \& Kabatereine, 2013). Procurement reforms in most African countries were however, driven by the need to meet the requirements set to earn donor funding (Basheka \& Kabatereine, 2013; Elegbe, 2015; Komakech, 2016).

\section{Public procurement in Zimbabwe}

The need to address a number of public procurement concerns including procurement planning, contract placement, contract administration (Arrowsmith, 2011), and the need to strike a balance between maximizing competition to ensure value for money, transparency, fairness, efficiency and exploration of e-procurement (Thai, 2006) had well justified the need for public procurement reforms in Zimbabwe. The public procurement reform program which was supported by a two-million grant from the World Bank's Zimbabwe Reconstruction Fund, has made significant progress in advancing these reforms, taking the form of the enactment of a new Public Procurement and Disposal of Public Assets Act (Chapter 22:23) as the anchor instrument of the legal framework, replacing the Procurement Act (Chapter 22:14) Act number 2 of 2009; the development of practical tools for implementing the law, including standard bidding and contract documents; and the development of an electronic government procurement strategy the e-GP.

The old legal and institutional arrangements for Zimbabwe's public procurement had a very high risk of encountering corruption, through for example, irregular payments and governance issues in connection with the awarding of public contracts, as well as favoritism in the decisions of government officials. As such, public funds were often diverted towards other non-value adding purposes. It can be expected that the procurement reforms in Zimbabwe are making transformational changes as seen by the replacement of the old procurement framework with a modern system that is more efficient, accountable and transparent. The specific steps taken towards this public procurement policy modernization include the adoption of modern public procurement regulations that define the legal, institutional and procedural frameworks. The Public Procurement and Disposal of Public Assets Act (Chapter 22:23) came into force in January 2018; establishment of the Procurement Regulatory Authority of Zimbabwe (PRAZ) and board appointed in January 2018, whose role among others is setting basis for enforcement of procurement regulations. Studies established the existence of a direct positive relationship between enforcement and compliance (Gunningham \& Kagan, 2005; Impecato, 2005; Zubcic \& Sims, 2011). Another important development was the crafting and rolling out of training of trainers' course 
materials aimed at promoting knowledge of the new regulatory provisions. Knowledge of regulatory provisions and requirements for good public procurement is important considering that power dynamics within state enterprises coupled by poor understanding of legal and regulatory provisions can be the basis for noncompliance. Public procurement is inherently subject to political arm-twisting (Pillary, 2004; Raymond, 2008), creating grounds for corruption (Tsabora, 2004; Raymond, 2008; Froystad, et al., 2010), which has a negative implication on compliance and transparency. Rolling out of the training program was also encompassed by professionalization and certification modules development. Literature points to the importance of the role played by professionalism in public procurement (Hunja, 2003; Goldernman, et al., 2010; Bhaseka \& Mugabira, 2008), whose value hinges much on staffing and resourcing decisions which should place great significance on the ethical status of procurement personnel (Lan, et al., 2005). Ethical and moral uprightness is central to the procurement profession (Saini, 2010).

To ensure the proper implementation of new public procurement system, the World Bank supported the establishment of the PRAZ, including a plan for developing quick wins during the first 100 days and a five year strategic plan 2019- 2023 that identifies five objectives, being, an improvement in public procurement effectiveness through targeted capacity building of market players; increasing competition of private sector in public markets; increasing value for money; increasing transparency and accountability in the public procurement processes and guaranteeing an efficient regulatory function which promotes regulatory compliance.

\section{Public procurement and public service delivery in Zimbabwe local authorities}

Public service delivery refers to the provision of services by public entities to its citizens, which are afforded regardless of class or economic status (Le Grand, 2009; Wanna, et al., 2010), meaning that the major tenets of a good public service are high quality and its equitable distribution. Public service delivery is funded by taxpayers, afforded without a profit motive and as such, it is not subjected to market forces. This effectively has a tendency to overshadow the incentive to create value for money for the taxpayer (Van Wheele, 2014), which is also complicated by the obscurity associated with as performance measures for its administration. It is therefore the role of public procurement to set premises to ensure there is creation of value and improvement in public service delivery (Vellapi, 2010). As much as literature sources argue on the ambiguity of measuring value addition in service delivery, public procurement can create value through its contribution towards achievement of government policy objectives while affording the best returns to the providers of finance, the taxpayers (Basley \& Ghatak, 2007; Weishaar, 2013). Effective public service delivery entails availing the basic resources to sustain human livelihood such as clean water, electricity and infrastructure (Murimoga \& Musingafi, 2014), however, these basic services are in critical deficit in Zimbabwe and the prevailing situation is negatively impacting the quality of lives of citizens. The current status has been blamed on poor maintenance, poor public finance management and general governance incompetency (Chirisa, 2010; International Republican Institute, 2015). Generally, these problems are blamed on poor corporate governance practices within the public sector. Owing to the lack of empirical literature on public procurement and service delivery, and to be able to assess the nature of the relationship between the independent and dependent variables, the proposed study hypothesis can be stated as:

$\mathrm{H}_{1}$ : There is a positive relationship between the efficiency of public procurement systems and the effectiveness of public service delivery in Zimbabwe local authorities.

\section{Proposed research framework}

Based on the limited literature concerning the influence of public procurement decisions on public service delivery, this study proposed the following framework that is expected to explain a considerable degree of variance in quality of public service delivery in Zimbabwe local authorities. 


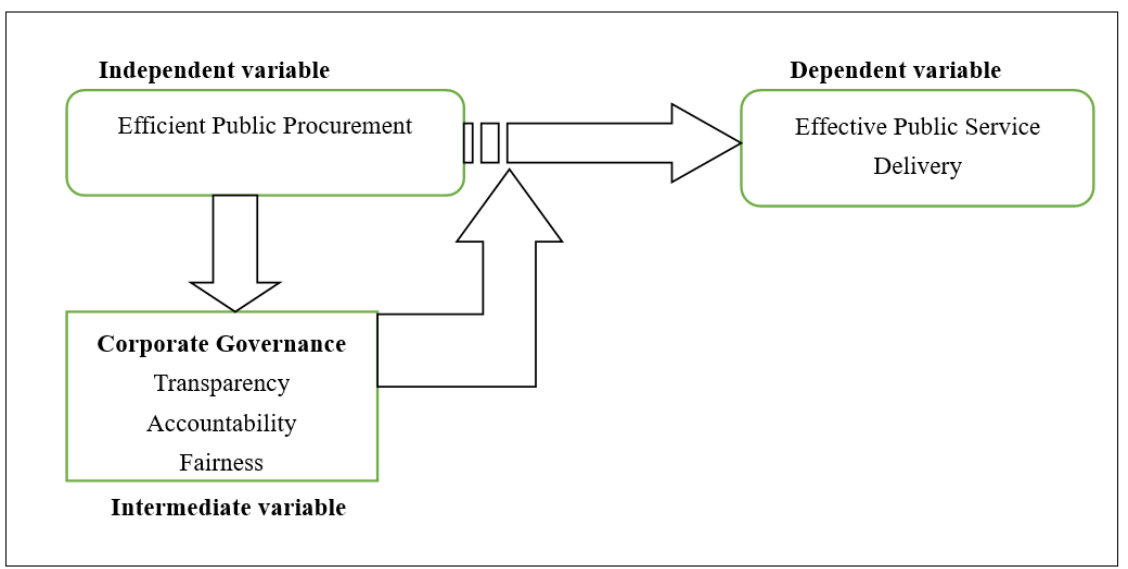

Figure 1: Proposed study conceptual framework

Source: Researcher conceptualization, 2019

\section{Conclusion and recommendations}

Public procurement is a business function within a political system (Watermeyer, 2011). In Zimbabwe it is estimated that $60 \%$ of government expenditure is allocated to public procurement (Mushanyuri, 2014), as such, it is clear that public procurement decisions significantly affect service delivery and public sector performance (Mutava, 2012; Sarfo \& Baah-Mintah, 2013; Thou \& Njeru, 2014). A handful of studies associate the poor and continuously declining quality of service delivery and public sector performance to poor implementation of government projects (Tsabora, 2004; Dzuke \& Naude, 2015), yet literature on the impact of public procurement decisions on public sector performance remains scant. In light of the poor state of public service delivery in Zimbabwe's public sector (Karombo, 2014; Uromi, 2014), this proposed study framework is aimed at making an important contribution towards awakening interest in policy making agencies and stakeholders on the importance and criticalness of the influence of public procurement decisions on public service delivery and redirect attention of future studies towards a further empirical analysis of the relationship between public procurement and public service delivery in Zimbabwe local authorities and beyond.

\section{References}

Agaba, E. \& Shipman, N., 2007. Public procurement reforms in developing countries: The Ugandan Experience. In: G. Piga \& K. V. Thai, eds. Advancing Public Procurement: Practices, Innovation and Knowledge Sharing. Boca Raton: Pr Academics Press.

Arrowsmith, S., 2011. Public procurement regulation: An Introduction. s.1.:University of Nottingham.

Basheka, B. C., 2013. The science of public procurement and administration. International Public Procurement Conference, pp. 20-330.

Basheka, B. C. \& Kabatereine, D., 2013. Public procurement reforms in Uganda. A historical trajectory. Journal of Public Procurement and Contract Management, 2(1), pp. 27-41.

Basley, T. \& Ghatak, M., 2007. Rerforming public service delivery. Journal of African Economies, 16(1), pp. $127-156$

Bhaseka, B. C. \& Mugabira, M. I., 2008. Measuring professionalism variables and their implication to procurement outcomes in Uganda. s.l., The Third International Public Procurement Conference Proceedings.

Callendar, G. \& Mathews, D., 2000. Government Purchasing: An evolving profession?. Journal of Public Budgeting, Accounting \& Financial Management, 2(2), pp. 272-290.

Chick, G. \& Handfield, R., 2014. The procurement value proposition: The rise of supply chain management. London: Kogan.

Chirisa, T., 2010. Social development in Zimbabwe. Discussion paper prepared for the Development Foundation for Zimbabwe. s.l.:s.n.

Coe, C. K., 1989. Public finance management. Englewood Cliffs: Prentice Hall.

Dzuke, A. \& Naude, M. J. A., 2015. Procurement challenges in Zimbabwe public sector: A preliminary study. Journal of Transport and Supply Chain Management, 9(1), pp. 1-9.

Elegbe, S. W., 2015. A comperative analysis of public procurement reforms in Africa: Challenges and prospects. Reprint from Procurement Law Journal, pp. 10-32.

Flynn, a. \& Paul, D., 2014. Theory in public procurement research. Journal of Public Procurement, 14(21), pp. $139-180$

Froystad, M., Heggstad, K. K. \& Fjeldstad, O. H., 2010. Linking procurement and political economy. s.1.:UK Department of International Development and the World Bank Institute. 
Fuwei, S., 1996. Cultural flow between China and the outside world through history. BeijingForeign Language Press: s.n.

Goldernman, K., Ghijsen, P. \& Schoonen, J., 2010. Eplaning non-compliance with European Union Procurement Directives: A multidisciplinary Perspective. Journal of Common Market Studies, 48(2), pp. 243-264.

Grimm, R. \& Thai, K. V., 2000. Symposium on government procurement, Part 1. Journal of Public Budgeting , Accounting \& Financial Management, 12(2), pp. 230-332.

Gunningham, N. \& Kagan, R. A., 2005. Regulation and business behaviour. Law and Policy, Volume 27, pp. 213-218.

Hunja, R. R., 2003. Obstacles to public procurement reform in developing countires. Public procurement the continuing revolution. s.1.:Kluwer Law International.

Impecato, G. L., 2005. Corporate crime, responsibility compliance and governance. Journal of Heath, Care and Complaince, 7(3), pp. 11-19.

International Republican Institute, 2015. Survey on local governance and constitutionalism in Zimbabwe. s.1.:International republican Institute on Advanced Democracy World wide.

Isohata, H., 2009. Historical study on the development of construction management system in Japan. Cottbus, Proceedings of the Third International Congress on Construction History.

Karombo, T., 2014. Zimbabwe's Netone under fire for poor performance. s.1.:s.n.

Keeney, S., 2007. The foundations of government contracting. Journal of Contract Management, pp. 7-19.

Komakech, R. A., 2016. Best public procurement systems in Uganda: Objectives, principles and required professional skills. Public Policy and Administration Research, 6(8), pp. 20-29.

Lan, Z. G., Riley, L. \& Cayer, J. N., 2005. How can local government become an employer of choice for technical professionals?. Review of Public Administration , 25(3), pp. 225-242.

Le Grand, J., 2009. The other invisible hand: Delivering public service through choice and competition. Princeton: Princeton University Press.

Livy, L., 1966. History of Rome XXIII-XXI. In: N. Luis \& M. Reinhold, eds. Roman Civilization: sourcebook 1. New York: Harper and Row Publishers.

Miller, N., 1992. Stealing from America: A history of corruption from Jamestown to Reagan. New York: Paragon House.

Murimoga, R. \& Musingafi, M. C. C., 2014. Local governance and service delivery in Zimbabwe local authorities the case of Harare and Masvingo urban municipalities. International Journal of Public Policy and Administration Research, 1(3), pp. 94-107.

Mushanyuri, B. E., 2014. Call for public procurement system review. s.l.:s.n.

Mutava, C., 2012. Impact of public procurement procedures on delivery of maintenance. s.1.:University of Nairobi.

Nuxoll, E. M., 2006. United States at War: Understanding conflict and society. Secret Committee of Congress. $A B C-C L I O$. Kansas City: Mid-Continent Public Library.

Odhiambo, W. \& Kamau, P., 2003. Public procurement: Lessons from Kenya, Tanzania and Uganda. The Intergration of Developing Countries into the World Trading System. s.1.:OECD Working Paper.

Pillary, S., 2004. Corruption the challenge to good governance. Benchmarking: An International Journal, 15(6), pp. 782-793.

Raymond, J., 2008. Bencmarking in public procurement. s.l.:s.n.

Saini, A., 2010. Purchasing ethics and inter-organisational buyer-supplier relational determinants: A conceptual framework. Journal of Business Ethics, Volume 95, pp. 439-455.

Sarfo, P. A. \& Baah-Mintah, R., 2013. Assessing the effect of the procurement Act (663) on the public financial management in Ashanti Region. American Journal of Rural Development, 1(4), pp. 91-98.

Siri, G., 2005. Procurement professionala and Ethics: A little history. s.1.:NCMA Tri Valley Chapter Times.

Thai, K., 2006. Challenges in public procurement. Boca Raton, Florida: Academics Press.

Thai, K. V., 2001. Public procurement re-examined. Journal of Public Procurement, 1(1), pp. 9-50.

Thou, C. W. \& Njeru, A., 2014. Effects of public procurement reforms on service delivery at National Spinal Injury Hospital in Nairobi. International Journal of Business and Commerce.

Tsabora, J., 2004. Public procurement in Zimbabwe. Law, Policy and Practice, 1(1).

Uromi, S. M., 2014. Challenges facing public procurement information in some African countries namely South Africa, Uganda, Zimbabwe and Tanzania. International Journal for Innovation Education Research, 2(7), pp. 54-60.

Van Wheele, A. J., 2014. Purchasing and supply chain management. 6th ed. Singapore: Cengage Learning .

Vellapi, M., 2010. Public procurement for sustainable development. Research paper on sustainable public procurement. SriLanka: Minstry of Highways.

Wanna, J., Butcher, J. \& Freyens, B., 2010. Policy in Action: The challenges of service delivery. Sydney: New South Publishing. 
Weishaar, E., 2013. Cartels, competition and public procurement: Law and Economic approaches to bid rigging. Chelteham: Edward Elgar.

Zubcic, J. \& Sims, R., 2011. Examining the link betwween enforcement activity and corporate compliance by Australian companies and the impications for regulators. International Journal of Law and Management, 53(4), pp. 299-308.

\section{About authors}

Moses Jachi is a lecturer in the Department of Accounting at Manicaland State University of Applied sciences, Zimbabwe. He is the corresponding author

Melania Makumbe is a lecturer in and Chairperson of the Department of Accounting at Manicaland State University of Applied Sciences, Zimbabwe. Her research interests concentrate on accounting education, taxation and public policy and administration.

Lucia Mandongwe is a lecturer in the Department of Accounting at Manicaland State University of Applied Sciences, Zimbabwe. Her research interests concentrate on management accounting and cost accounting, strategic management accounting and financial reporting. 